Article

\title{
Late Pleistocene Deer in the Region of the National Park "Serra da Capivara" (Piauí, Brazil)
}

\author{
Andrea M. F. Valli
}

Société Scientifique du Bourbonais, Moulins, F03000 Allier, France; andrea_vallifr@yahoo.fr

Academic Editor: Maria Rita Palombo

Received: 6 January 2018; Accepted: 12 March 2018; Published: 14 March 2018

\begin{abstract}
The analysis of the cervid fossil remains from the late Pleistocene fossiliferous deposit Lagoa dos Porcos (in the region of the National Park "Serra da Capivara", Piauí, Brazil) proves the presence of at least two species: a small deer, belonging to the genus Mazama, and a larger one (Morenelaphus sp.). The latter taxon is recognized for the first time not only in this area, but in the whole Piauí State, enlarging the paleogeographic distribution of the genus. This study also points out the difference between the cervid fauna found in the karstic area of Park and Lagoa dos Porcos, which lies in the alluvial plain.
\end{abstract}

Keywords: Nordeste; cervidae; ecological comparison; Mazama; Morenelaphus

\section{Introduction}

The region of the National Park "Serra da Capivara" (Piauí, Brazil), recognized as a UNESCO World Heritage site, includes several paleontological localities that have given us thousands of late Pleistocene-early Holocene fossils [1,2] making this area crucial for a better understanding of mammalian evolution and paleoenvironment reconstruction in the Brazilian region called Nordeste. With several thousand fossil bones and various human artefacts, the Lagoa dos Porcos (Figure 1) is one of the richest sites in the country [3].

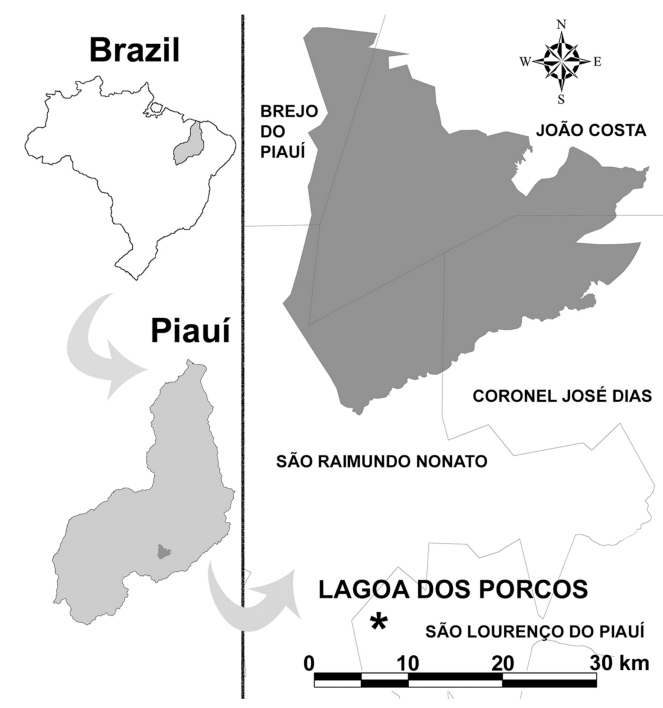

Figure 1. The National Park Serra da Capivara (dark grey) within the Piauí State, location of the Lagoa dos Porcos fossiliferous deposit and the main municipalities of the area (modified from Guérin and Faure [1]). 
The Lagoa dos Porcos $\left(9^{\circ} 9^{\prime} 10.94^{\prime \prime} S ; 42^{\circ} 38^{\prime} 59.04^{\prime \prime} \mathrm{W}\right)$, like all the other lagoa deposits of the region, is a depression in the Precambrian granite-gneiss basement, occasionally filled by water (and sediments) during the periods of intense hydro-environmental conditions (e.g., the humid seasons). These depressions also acted as traps for bones and carcasses at such times. After fossilization, the remains may appear on the surface due to erosion or from human excavations performed in the area to find or collect water. The fossils presented here were recovered in this way from the Lagoa dos Porcos.

One area of $80 \mathrm{~m}$ diameter was dug during 2010-2012, approximately in the central part of the lagoa with the purpose of collecting fossil remains. Three layers have been recognized (Figure 2). From the top to the bottom: (i) a mud layer rich in organic matter (Layer 1); (ii) a medium-coarse sand with clay (Layer 2); (iii) a thin but rich fossiliferous layer (Layer 3) of conglomerate sediments with pebbles (mainly quartz), gneiss fragments, and bones belonging to a Late Pleistocene megafauna. Two fossil samples (two teeth, a Toxodontidae Owen, 1945 and a Gomphoteridae Hay, 1922) have been dated by the electron spin resonance (ESR) method giving as results, respectively, $26 \pm 4 \mathrm{ka}$ and $23 \pm 3 \mathrm{ka}[4]$. However, the sediments overlying the paleofauna remains have been dated at about 17,000 years BP [3].

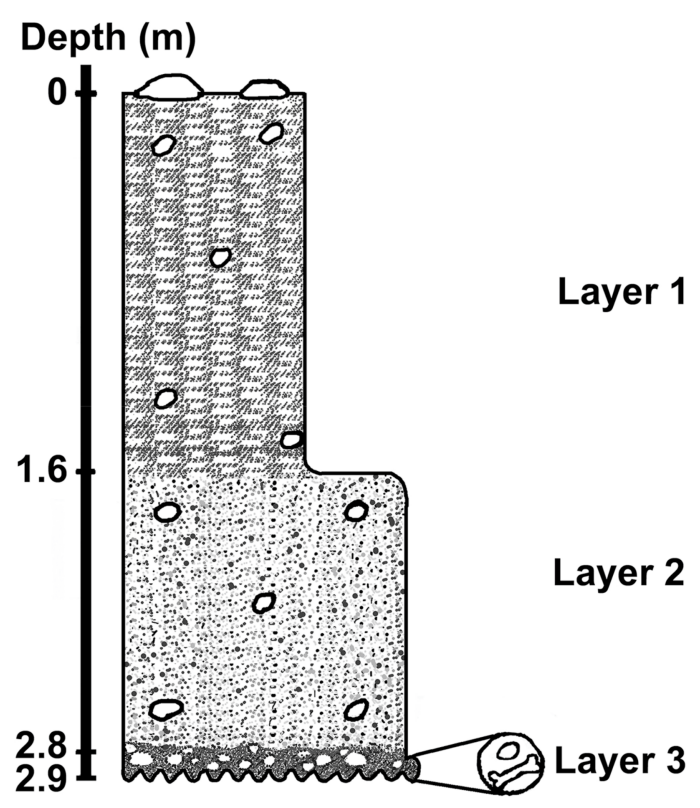

Figure 2. Schematic stratigraphy of studied site showing the three layers excavated (modified from Felice et al. [3]). Layer 1: mud layer rich in organic matter; Layer 2: medium-coarse sand layer with clay; Layer 3: conglomeratic sediments with pebbles (mainly quartz), gneiss fragments, and fossil bones.

The majority of the fossilized bones are represented by skeleton elements of a large number of ground sloth individuals. Despite this fact, because of its richness, the locality promises to provide materials for many scientific productions on different taxa. At present, it has produced a complete skull of a new genus and species of Toxodontidae (Piauhytherium capivarae Guérin and Faure, 2013) [5], and a hemi-mandible of a very young ground sloth, identified as Eremotherium rusconii (Schaub, 1935) [6], although the validity of this taxon has been questioned, and some researchers consider it a junior synonym of Eremotherium laurillardi (Lund, 1842) (see e.g., Cartelle et al. [7] and references therein).

The aim of this paper is to describe the cervid fossils recovered at the site Lagoa dos Porcos. They include several deer remains, and fragments of antlers of a medium-large taxon [1]. Fossil antlers have rarely been found in this region; the specimens from the Lagoa dos Porcos are far from complete, but enough to affirm that they belong to a taxon not yet reported in this area. 


\section{South America Fossil Deer}

The family Cervidae evolved in Eurasia during the early Miocene [8-10] and dispersed to the Americas, crossing the Bering Strait, possibly about $5 \mathrm{Ma}$ ago [11]. Nevertheless, no reliable records of their presence are, however, reported in South America earlier than the Ensenadan (early Pleistocene-middle Pleistocene) South American Land Mammal Age (SALMA) [12,13]. Today, on this continent, they constitute a well-diversified family, with at least 17 species, belonging to six genera [14-16]. Blastocerus Wagner, 1844, and Ozotocerus Ameghino, 1891, are mono-specific, while Pudu Molina, 1782, Hippocamelus Leuckart, 1816 and Odocoileus Rafinesque, 1832 have two species each (but regarding Odocoileus, only one reaches the South America [17]: Odocoileus virginianus (Zimmermann, 1780)). Finally, Mazama Rafinesque, 1817, the genus of the brocket deer, is the richest in species: it counts nine or ten taxa, depending on the author $[14,15,18]$. It is also the most problematic group from a taxonomical point of view and with regard to the inter-specific relationships $[19,20]$. Recently, its monophyly has been challenged, mainly by molecular studies, and the genus could be split, at least, in two taxa. In fact, the red brocket, Mazama americana (Erxleben, 1777) would be more closely related to the white-tailed deer, O. virginianus, than to other Mazama species [21-23].

All the modern genera have been recognized in various South American Pleistocene localities and their remains have been attributed both to extant and extinct species [14,24-27]. Even the genus Pudu, despite the fact that all the remains that have been recognized have always been criticized, seems to have left its "marks" during the late Pleistocene: recently, a third cervical vertebra from a Chilean fossiliferous deposit has been described and determined as "cf. Pudu" [28].

\subsection{Modern Genera in the Nordeste}

An account of the distribution of the modern cervid species into the South American continent during the late Pleistocene-early Holocene can be found in Guérin and Faure [26] and Merino and Rossi [14]. Here, we briefly indicate their occurrences in the Nordeste, the region where the Lagoa dos Porcos is located.

According to Cartelle [25], late Pleistocene remains of O. virginianus have been collected in Bahia State. Fossils of Mazama are often reported without a more specific identification, in this region, as well as in other parts of Brazil. The species M. americana and Mazama gouazoubira (Fischer 1814), the grey brocket, have been reported in various late Pleistocene-early Holocene paleontological deposits in the Nordeste: the first taxon would be present in Piauí and Bahia States, the latter in Ceará, Rio Grande do Norte, Paraiba, Bahia, and Piauí $[25,26,29,30]$. The Pampas deer, Ozotoceros bezoarcticus (Linnaeus, 1758), is reported in Ceará and Bahia States [25,29], as well as in Pernambuco (Lagoa da Pedra [31]). However, the last identification needs to be confirmed [32]. The fossil species Hippocamelus sulcatus (Ameghino, 1889) has been reported in Penambuco State [33]. Nevertheless, its authenticity is still debated [29]; so, its presence needs to be confirmed. Finally, the marsh deer, Blastocerus dichotomus (Illiger, 1815), has been signaled in the Piauí State [26].

\subsection{Fossil Cervid Genera}

During the Pleistocene, the deer family was much more diverse in South America than it is today; it included at least six different extinct genera [14]. Two of these, Agalmaceros Hoffstetter, 1952 and Charitoceros Hoffstetter, 1963, include no more than one species each: Agalmaceros blicki (Frick, 1937) and Charitoceros tarijensis (Hoffstetter, 1952). These taxa are only known in the Pleistocene localities where they were described: the Andes of Ecuador and the deposits of Tarija, Bolivia, respectively [14]. Even the genus Paraceros Ameghino, 1889 includes only one species: Paraceros fragilis (Ameghino, 1888). It has been recorded in Buenos Aires and Santa Fe Provinces, Argentina, during the Ensenadan and the Bonaerian (middle Pleistocene) SALMA [14], as well as in Uruguay [34,35].

The genus Epieuryceros Ameghino, 1889, comprises two species: Epieuryceros truncus Ameghino, 1889, of the Ensenadan, and Epieuryceros proximus Castellano, 1945, of the more recent Bonaerian and 
Lujanian (late Pleistocene-Holocene). The presence of Epieuryceros seems limited to Argentina [36]; the report of the genus in the State of Rio Grande do Sul, Brazil needs confirmation [30].

The genus Antifer Ameghino 1889 includes three species. The first one, Antifer ensenadensis (Ameghino, 1888), seemed limited to the Argentinian Ensenadan, but it has been recognized even in the Lujanian-aged sediments $[37,38]$. Antifer ultra (Ameghino 1888) is recorded in the Bonaerian and the Lujanian, not only in Argentina and Uruguay, but, possibly, in Brazil and Chile [34,36,39-42]. In the last two countries, the taxon is often reported as Antifer sp., but the size and the morphology of the specimens are in agreement with those of A. ultra. The last species, Antifer niemeyeri Casamiquela, 1984, is recorded in the late Pleistocene of Chile (Casamiquela, 1984). However, its validity has been challenged: according to Labarca and Alcaraz [27], A. niemeyeri would only be a younger synonym of A. ultra.

Finally, Morenelaphus Carette, 1922 is known by two species initially considered to have lived during different temporal ranges (allochronous), Morenelaphus brachyceros Gervais and Ameghino, 1880, Bonaerian, and Morenelaphus lujanensis Ameghino, 1888, Lujanian. Nevertheless, Alcazar [38], found both the taxa existing in the Bonaerian to the Lujanian of Argentina. The geographic distribution of the genus includes Argentina, Paraguay, Uruguay and Brazil [14,43-45]. In particular, it was reported in Pernambuco State by Cartelle [24].

Concerning the area of the National Park "Serra da Capivara", three cervid species have been mentioned during the late Pleistocene-early Holocene: B. dichotomus, M. gouazoubira and M. americana [26]. Their fossils have been collected in the karstic area of the Barra Bonita Formation [2], in proximity to the southeastern boundaries of the National Park.

The Lagoa dos Porcos, as well as other lagoa deposits of the region, lies in a completely different sedimentary complex: the alluvial plain, extending south of the National Park. This study not only presents the taxa recognized in the Lagoa, but also offers the possibility of a preliminary comparison, concerning the cervid faunal composition, from two different sets of sites in the same region.

\section{Materials and Methods}

The nomenclature for bones, teeth and anatomical features follows Benton [46] and Gustafson [47]. For deciduous teeth, we use the terminology employed for molars. The measurements have been made by a caliper: they have been performed as shown in Desse et al. [48] and Valli [49].

Antero-posterior and transversal diameters of the beam of antler fragments were taken just above the first tine. The height of the first fork was measured from the base of the burr to the concavity above the first tine. The measurement error is put at $0.5 \mathrm{~mm}$ (except for statistical calculations).

The following abbreviations can be seen in the text, figures, and tables: alv: alveolar; DAP: antero-posterior diameter; DDV: dorso-ventral diameter; Dist: Distal; DT: transversal diameter; H 1 Fork: height of the first fork; I lb: first lobid; II lb: second lobid; III lb: third lobid; L: left; Lat: lateral; max: maximum; Med: medial; Mid: Midshaft; min: minimum; NPSC: National Park "Serra da Capivara"; Prox: Proximal; R: right; and Tot: Total. The teeth are indicated by M and $\mathrm{m}$ (upper and lower molar respectively), $\mathrm{P}$ and $\mathrm{p}$ (upper and lower premolar respectively), and $\mathrm{D}$ and $\mathrm{d}$ (upper and lower lacteal tooth).

The studied fossils of the Lagoa dos Porcos are indicated using the complete numeric code marked on them. It includes the site code (in this case "1302") and the univocal number associated with each specimen, which may or not be followed by an extension (e.g., 1302-182333-8). The fossils described in this paper are all housed at the Fundação Museu do Homem Americano (FUMDHAM), in São Raiundo Nonato (Piauí, Brazil). They have been compared with the modern material from the Museu Nacional de Rio de Janeiro (MNRJ, Rio de Janeiro, Brazil) and the American Museum of Natural History (AMNH, New York, NY, USA), and with the information (measurements and illustrations) obtained from the cited bibliography. 


\section{Specimens Description}

\subsection{The Smaller Taxon}

Two remains, 1302-183765 and, possibly, 1302-190885, belong to a small cervid. The second specimen is a fragment of right mandible with $\mathrm{d} 2-\mathrm{m} 1$. The anterior portion is broken just in front to the mental foramen. The $\mathrm{d} 2$, the first lower lacteal tooth, is triangular in shape with two cusps, the anterior one prolonged by a tiny stylid crest. The $\mathrm{d} 3$ is also triangular, but with two clear notches (one on the lingual side, in the anterior part of the tooth, the second, closer, on the other side), between the protoconid and the hypoconid. This last lobid is clearly protruding labially.

The $\mathrm{d} 4$ looks like a miniature $\mathrm{m} 3$, but the smallest lobid is the first, not the last one. In addition, the anterior edge, in lateral view, is not vertical but at an angle oblique. The protoconid and the hypoconid are triangular in shape, without ectostylid between them.

On the $\mathrm{m} 1$, the external lobids (protoconid and hypoconid) are triangular, without ectostylid or ectocingulid. On the anterior part, the mesostylid joins the anterior cingulid to form an anterior cristid, slightly oblique to the row axis (Figure 3). On the lingual side, the metaconid and the entoconid are clearly marked; the metastylid is present, but less pronounced. The posterior fossetid is closed by the highly developed posthypocristid.

The specimen $1302-183765$ is a left $\mathrm{m} 1$ or $\mathrm{m} 2$. It is very similar to the other lower molar, but lacks the anterior cristid. The posthypocristid is also less posteriorly developed, but it could just be an effect of dental wear. The measurements are given in the Table 1.

Table 1. Lower teeth (in $\mathrm{mm}$ ).

\begin{tabular}{ccc}
\hline Measurement & 1302-190885 & 1302-183765 \\
\hline d2, Tot DAP & 6.0 & - \\
d2, alv DAP & 4.5 & - \\
d2, DT & 3.5 & - \\
d3, Tot DAP & 9.0 & - \\
d3, alv DAP & 7.5 & - \\
d3, DT & 4.5 & - \\
d4, Tot DAP & 18.5 & - \\
d4, alv DAP & 15.5 & - \\
d4, DT I lb & 5.0 & - \\
d4, DT II lb & 6.5 & - \\
d4, DT III lb & 6.5 & - \\
m1, Tot DAP & 17.0 & - \\
m1, alv DAP & 14.5 & - \\
m1, DT I lb & 7.5 & - \\
m1, DT II lb & 7.0 & - \\
d2-d4, Tot DAP & 31.5 & - \\
d2-d4, alv DAP & 26.0 & 12.5 \\
m, Tot DAP & - & 11.0 \\
m, alv DAP & - & 7.0 \\
m, DT I lb & - & 7.5 \\
m, DT II lb & - &
\end{tabular}

DAP: antero-posterior diameter; alv: alveolar; DT: transversal diameter; I lb: first lobid; II lb: second lobid; III lb: third lb; m: lower molar; d1-4: lacteal lower tooth 1-4; Tot: total. 


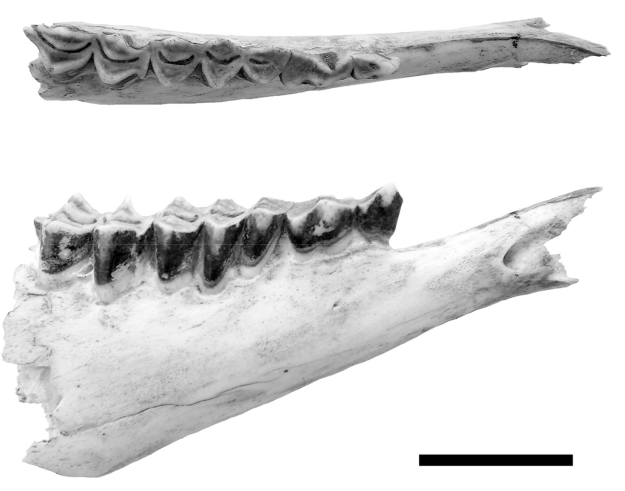

Figure 3. Right mandible 1302-190885 with d2-m1: above, vertical view; below, lateral view. Scale bar $=20 \mathrm{~mm}$.

Another specimen seems to belong to a small cervid: the phalanx I 1302-184925 (Figure 4). Its attribution is discussed in section "Discussion". Its measurements are given in Table 2.

Table 2. Measurements (in $\mathrm{mm}$ ) of the cervid postcranial bones.

\begin{tabular}{ccccc}
\hline Measurement & $\begin{array}{c}\text { Small Cervid } \\
\text { Phalanx } \\
\text { I1302-184925 }\end{array}$ & $\begin{array}{c}\text { Morenelaphus? } \\
\text { R Metacarpal } \\
\text { 1302-183138 }\end{array}$ & $\begin{array}{c}\text { Morenelaphus? } \\
\text { R Tibia } \\
\text { 1302-183618-7 }\end{array}$ & $\begin{array}{c}\text { Morenelaphus? } \\
\text { R Talus } \\
\text { 1302-182333-8 }\end{array}$ \\
\hline Tot length & 38.5 & $\sim 201 *$ & 293.0 & - \\
Prox DT & 13.0 & 29.0 & nut55.0 & 25.5 \\
Prox DAP & 17.5 & 22.0 & 56.0 & - \\
Mid DT & 9.5 & 17.5 & 24.5 & - \\
Mid DAP & 12.5 & 18.0 & 20.0 & - \\
Sovraticular DT & - & 28.5 & - & - \\
Dist DT & 11.5 & 29.5 & 34.5 & 25.0 \\
Dist DAP & 11.5 & 20.0 & 29.5 & - \\
Tot height & - & - & - & 38.0 \\
Max DT & - & - & - & 25.5 \\
Lat height & - & - & - & 37.0 \\
Lat DAP & - & - & - & 20.0 \\
Med height & - & - & - & 35.0 \\
Med DAP & - & - & - & 20.0 \\
Middle height & - & - & & 30.0 \\
\hline
\end{tabular}

* The bone is broken, approximately, in the middle part of the shaft. Dist: distal; Lat: lateral; Med: medial; Mid: Midshaft; Prox: proximal; R: right.
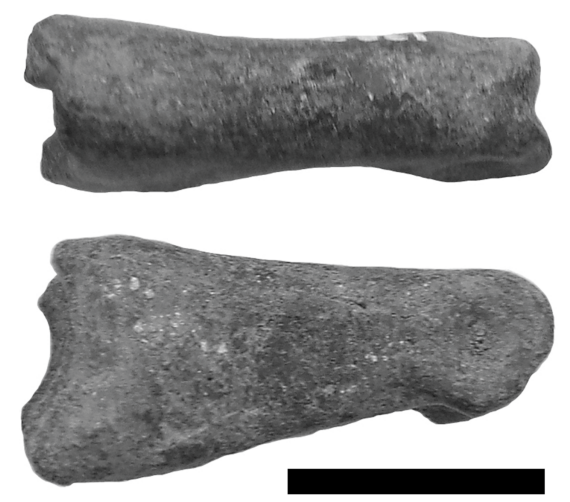

Figure 4. Phalanx I 1302-184925: above, vertical view; below, lateral view. Scale bar $=20 \mathrm{~mm}$. 


\subsection{The Larger Taxon}

Twelve remains, nine antler fragments (1302-181782-1; 1302-181962-1;1302-182999; 1302-183400-1; 1302-184030-1; 1302-185423 9; 1302-186038-1; 1302-188188-2 and 1302-196671) and three postcranial bones (right metacarpal III + IV 1302-183138; right tibia 1302-183618-7 and 1302-183557-23; right talus 1302-182333-8) belong to a medium-large species.

On the antlers, the burr (when not erased by taphonomic agents, as on the specimen 1302-188188-2) is composed of bony outgrowths. The shaft is cylindrical, slightly flattened medio-laterally. The first tine (or brow tine) is positioned a short distance from the burr and its angle with the beam is always obtuse (1302-181962-1, 1302-183400-1, 1302-185423-9, 1302-186038-1; Figure 5a). At the level of the first dichotomy, the internal side of the shaft is always flat, and the external is concave. The specimens 1302-181962-1 and 1302-183400-1 present, on their internal side, some small pearls. Even the specimens 1302-188188-2 and 1302-196671 have pearls, but, because of the uncertain position of the fragment of the antler, it is not possible to state the exact side where it occurs. The last specimen, in particular, despite its diminutive size (its total length is only $101 \mathrm{~mm}$ ), seems to be a part of the beam (Figure 5c).

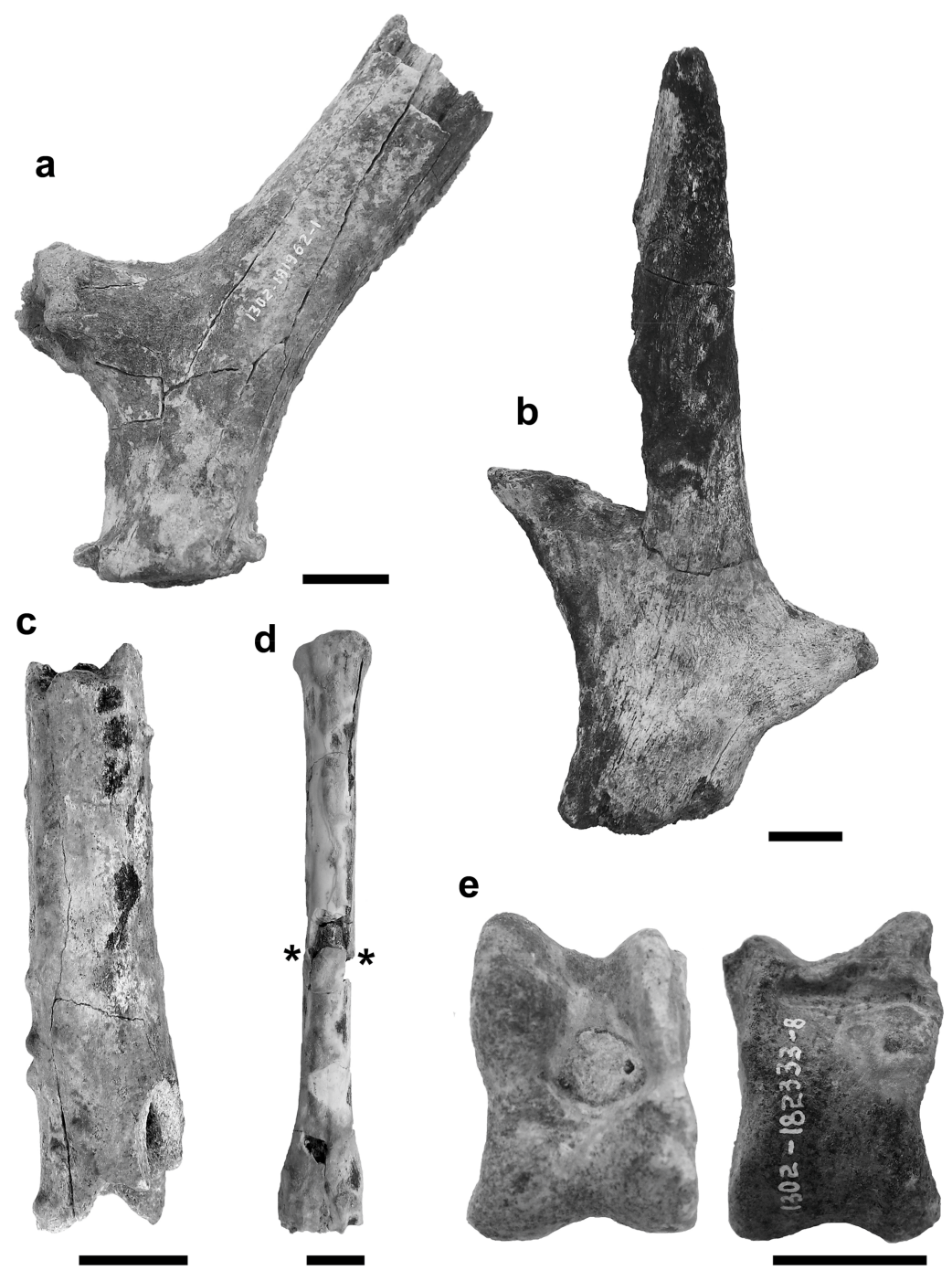

Figure 5. (a) Base of left shed antler 1302-181962-1, lateral view; (b) terminal part of brown tine or the top of beam 1302-184030-1; (c) fragment of the beam 1302-196671; (d), right metacarpal III + IV 1302-183138, dorsal view (the bone is broken at level of the asterisks); (e) right talus 1302-182333-8, dorsal view (left), plantar view (right). Scale bars $=20 \mathrm{~mm}$. 
The specimen 1302-186038-1 has a smoother surface, with poorly marked transversal grooves on the lateral side, below the first dichotomy. It is not possible to clearly examine the surface of the 1302-185423-9. The specimen 1302-184030-1 is the terminal part of a brown tine or the top of the beam. It is compressed and includes three points, the middle one being the most prominent (Figure 5b). Flattening of the terminal points can be seen in Morenelaphus specimens (compare our Figure 5b with the Plate 12, in Alcaraz's thesis; [38]). Our fragment measures $197 \mathrm{~mm}$ from the broken base to the top of the main point. Finally, the specimens 1302-181782-1 and 1302-182999 are fragments of tines. The first one is about $180 \mathrm{~mm}$ long; its tip is broken off and its surface is smooth. The second is about $180 \mathrm{~mm}$ long and its surface is covered with small pearls, especially near to its base. A very similar feature can be seen on an M. lujanensis' antler [38] (Plate 18A).

The measurements of the bases of antlers from the Lagoa dos Porcos are given in Table 3.

Table 3. Measurements (in $\mathrm{mm}$ ) of the bases of antlers from the Lagoa dos Porcos.

\begin{tabular}{ccccc}
\hline Measurement & $\mathbf{1 8 3 4 0 0 - 1}(\mathbf{L})$ & $\mathbf{1 8 1 9 6 2 - 1}(\mathbf{L})$ & $\mathbf{1 8 6 0 3 8 - 1 ~ ( R ) ~}$ & $\mathbf{1 8 5 4 2 3 - 9}$ (R?) \\
\hline DT of the burr & 46.0 & 36.0 & 35.5 & 34.5 \\
DAP of the burr & 49.5 & 41.5 & 37.0 & 39.0 \\
DT of the base of the shaft & 33.5 & 30.0 & 28.0 & 26.0 \\
DAP of the base of the shaft & 38.0 & 33.0 & 35.5 & 28.0 \\
H 1 fork & 71.5 & 62.5 & 50.5 & 59.5 \\
DT of the base of the first tine & 28.5 & 22.5 & 19.0 & - \\
DAP of the base of the first tine & 30.0 & 29.5 & 27.0 & 23.5 \\
DT of the beam & 32.0 & 31.0 & 26.0 & - \\
DAP of the beam & 45.0 & 40.0 & 35.0 & - \\
DT of the burr & 46.0 & 36.0 & 35.5 & 34.5 \\
DAP of the burr & 49.5 & 41.5 & 37.0 & 39.0 \\
DT of the base of the shaft & 33.5 & 30.0 & 28.0 & 26.0 \\
DAP of the base of the shaft & 38.0 & 33.0 & 35.5 & 28.0 \\
H 1 fork & 71.5 & 62.5 & 50.5 & 59.5 \\
DT of the base of the first tine & 28.5 & 22.5 & 19.0 & - \\
\hline
\end{tabular}

H 1 Fork: height of the first fork; L: left

The right metacarpal III + IV 1302-183138 is slender with well-defined articular keels for the phalanges (Figure 5d). At the proximal end, the articular surface is triangular (a real asymmetric triangle) in outline, with a rounded anterior corner (Figure 6a). No spurs seem present on the inner side of the proximal end.

The right tibia 1302-183618-7 and 1302-183557-23 has two label numbers because two distinct fragments have been recognized as belonging to the same specimen only after the numeration, before gluing them together. The first one corresponds to the proximal epiphysis with the whole diaphysis, the second number matches up with the distal epiphysis. The tuberosity in the posterior side of the proximal epiphysis is square-shaped in plantar view (Figure 6c). The tibial crest is strong and reaches one-third of the total length of the shaft. In distal view, the astragal articulation is clearly asymmetrical, with the lateral side less protruding than the medial one, making it trapezoidal-shaped in distal view. Still in distal view, the two lateral malleolar surfaces have different sizes (Figure 6b).
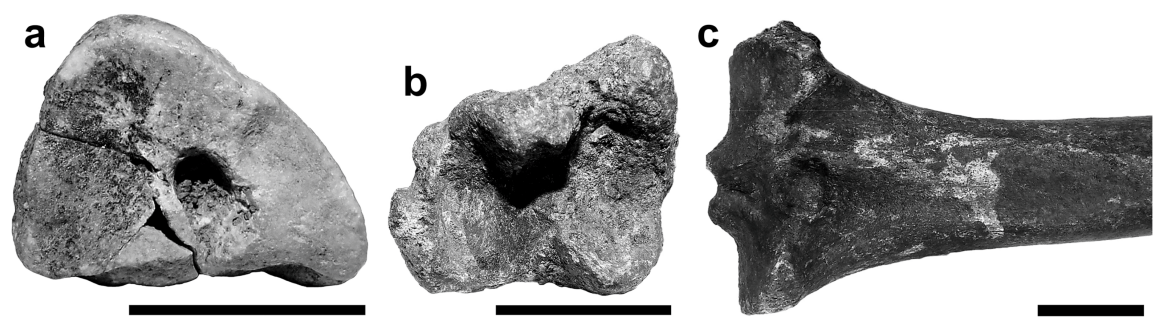

Figure 6. (a) Right metacarpal III + IV 1302-183138, proximal view; (b) right tibia 1302-183618-7 and 1302-183557-23, distal view; and (c) posterior view of the proximal end. Scale bars $=20 \mathrm{~mm}$. 
The right talus 1302-182333-8 shows a distal trochlea formed by two halves with the same width, but not the same symmetry (Figure 5e). The proximal-medial ridge is continuous, without a break. On the whole, it presents a pattern generally met on the cervid talus. All the measurements of the postcranial bones are shown in Table 2 .

\section{Discussion}

\subsection{The Cervid Taxa}

The size and the shape of the teeth 1302-190885 and 1302-183765-the smaller cervid from Lagoa dos Porcos-agree with those attributed by Guérin and Faure to M. americana [26]. The authors mentioned the red brocket in several late Pleistocene-early Holocene sites (Toca do sítio do Meio, Toca dos Pilão, Toca da Janela da Barra do Antonião, Toca do Gordo do Garrincho and Toca do Serrote do Artur). Because of the complex taxonomy of the group and due to the incompleteness of the material, we leave the remains from the Lagoa dos Porcos in open nomenclature as Mazama sp.

As far as the specimen 1302-190885 is concerned, the size and morphology of teeth match those shown by the specimen 22-27920-1 (see Table S4 in [26]) collected in the Toca do sítio do Meio, which belongs to a young animal. In particular, the deciduous teeth and the $\mathrm{m} 1$ are identical to those of 1302-190885, except for the development of the anterior cingulid of $\mathrm{m} 1$ (a minor feature). The mandibular branch of the specimen 1302-190885, however, seems too deep, with the measurements falling slightly outside the highest values measured for the taxon. The discovery of new material may allow a more accurate identification of this specimen.

The phalanx I 1302-184925 (Figure 4) is even more difficult to identify due to the lack of a consistent reference sample. It has been tentatively attributed to the same taxon as the teeth because of its general morphology and because it is larger than all the other phalanges gathered in the area (collected from fossiliferous deposits or obtained from dead modern specimens) and related to M. gouazoubira [26]. The red brocket weighs on average $30-35 \mathrm{~kg}$, but it can go up to $65 \mathrm{~kg}$ [15]. A phalanx I like the specimen 1302-184925 could belong to such a taxon. It is worth mentioning that the Pampa deer weighs from $22 \mathrm{~kg}$ up to $40 \mathrm{~kg}[15,50]$. However, the phalanx 1302-184925 does not match with Ozotoceros' bones, which are slightly longer and more tapering. However, our comparative sample includes only one individual with the phalanges glued together; so our measurements are not too accurate. Possibly, only further studies (and additional remains) from this area could determine if another cervid species is present in the region or not.

M. americana (the taxon already reported in this region, to which the remains described in this work may belong) is the largest and the most robust of the brocket deer [14,15] and lives in almost all the tropical regions of the South America. In particular, it is spread in the countries to the East of the Andes, from Colombia and Venezuela to Southern Brazil, Northern Argentina and Paraguay, except for same areas on the Atlantic coast and the oriental half of the Nordeste. It inhabits various kinds of primary and secondary forests, including campos, cerrados and semi-deciduous woods [15,51]. At present, the species is also noted inside NPSC, but the sample could represent a relict population from a species which was once ubiquitous [52].

It is worth mentioning that a fragment of left mandible ( $\left.n^{\circ} 398\right)$, and a metatarsal bone $\left(n^{\circ} 397\right)$ from the Tarija site (Bolivia), conserved at the Muséum national d'Histoire naturelle of Paris, have been attributed to M. americana by Guérin and Faure [26]. If confirmed, this record attests the presence of the red brocket on the continent since the middle Pleistocene.

As far as the larger taxon is concerned, its antlers cannot belong to Epieuryceros, whose frontal appendices show a peculiar structure typical of this genus (beam laterally compressed from the rose with the flattening which is accentuated towards the extremity), at least of adult individuals. Even the genus Antifer can be discarded because of its morphology. In fact, the profile of the rear part of Antifer's beam and the shape and implantation of its first tine (see Figures 15-17 in [53], and Figures 3 and 4 in [27]) are different from those of our fossils. They could scarcely belong to Paraceros. 
The main difference between Paraceros' and Morenelaphus' frontal appendices, whose recognition is based on its antlers (the most important kind of fossil deer collected in the Lagoa dos Porcos deposit), involves the position of the first tine, which is placed in sub-basal position in Morenelaphus, and higher in Paraceros. In addition, Paraceros' tines and beam have a surface which is basically smooth. On the other hand, Morenelaphus can present smooth grooves, striations and pearls [38]. The fragment of antler 1302-196671 shows several pearls on its surface, more appropriate for Morenelaphus than for the previous genus (e.g., compare Figure 5c with Figure 21a in [38]).

The antler fragments cannot belong to the extant genus Odocoileus, Hippocamelus, Blastocerus and Ozotoceros. The frontal appendices of the first two taxa have a peculiar shape at their base, completely different from the morphology of the specimens from the Lagoa dos Porcos. Hippocamelus lacks a first tine pointing forward, and Blastocerus has an almost symmetric fork with the first tine and the beam is directed upwards. Ozotoceros has antlers those shaft, between the burr and the first tine, are concave on the front side and convex on the rear. Our fossil specimens have a straighter shaft, at most, with a slight concavity in the rear part. Ozotoceros' shaft has a bigger variability than Blastocerus', but the angle between the beam and the first tine is never obtuse, as it is seen in our fossils. Its burr, as well as that of Blastocerus, is very strong, consisting of a set of very developed bony outgrowths. In fact, we must be very careful with this last feature, because the taphonomic processes could erase it. The shaft of both modern taxa present furrows and spurs more marked than those from our fossils. Possibly, over all, the large deer from the Lagoa of Porcos, shows the most striking similarities with the taxon M. lujanensis (comparing its features with the ones listed in Alcaraz [38] (pp. 186-188). Even the size is well suited to such a taxon: B. dichotomus' sample is, on average, significantly larger, and O. bezoarticus', smaller (Figure 7). We can therefore identify our deer as Morenelaphus sp. (for a more precise diagnosis it would be necessary more and better preserved material).

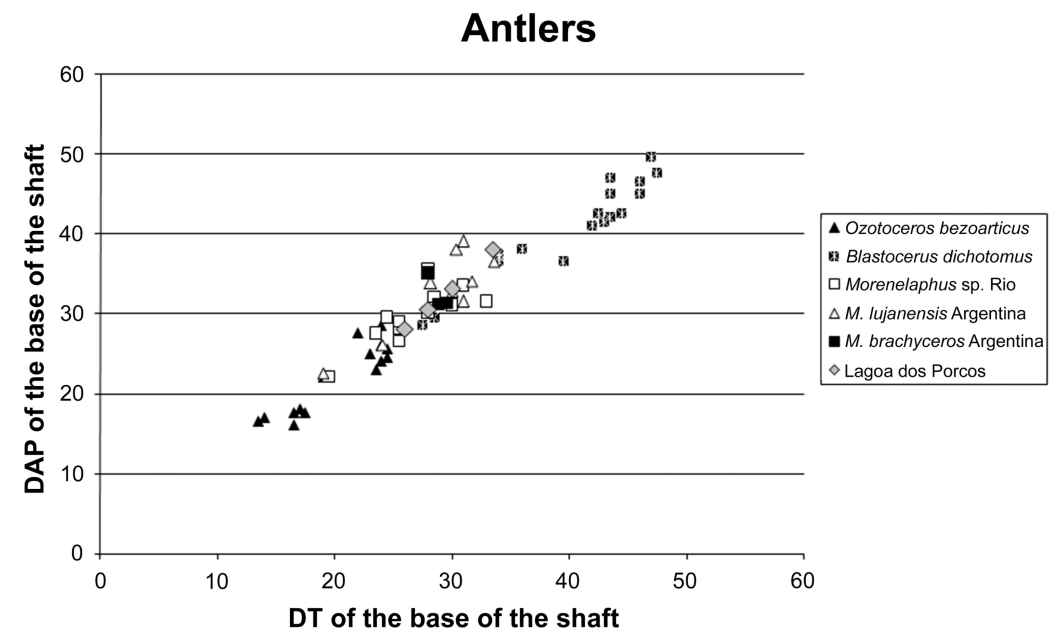

Figure 7. Scattering diagram of the DT versus the DAP $(\mathrm{mm})$ of the base of the shaft for some South American fossil and modern deer's antlers ("Lagoa dos Porcos", data from Table 3; "M. brachyceros Argentina" and "M. lujanensis Argentina" data from Alcazar [38]; others, author data).

It is much more complicated to compare its postcranial bones with other specimens belonging to Morenelaphus, because information is really scarce in scientific literature. Only Cartelle [43] writes about some teeth and leg bones attributed to such a taxon. They have been found in the Municipality of Janaúba (Minas Gerais, Brazil), where antler fragments, attributed to Morenelaphus, have also been collected. Be that as it may, the author did not have the opportunity to provide any descriptions or diagnostic pictures either for the denture nor for the postcranial elements.

Our talus (1302-182333-8) is morphologically identical to the bone from the Toca da Janela da Barra do Antonião (184-9871), cited and measured by Guérin and Faure (see Table S11 in [26]) and attributed 
to the marsh deer. Its dimensions are very similar, even if the fossil from the last locality looks slightly stockier than that from the Lagoa dos Porcos. This fact raises the problem of distinguishing Morenelaphus' bones from Blasthocerus' ones, or in general, to adequately identify the postcranial remains of the medium-large fossil deer. In fact, the extinct cervids from South America are characterized exclusively by their antlers $[53,54]$.

The problem arises, here, in NPSC, where some bones have been attributed to B. dichotomus [26]. The material consists of a few teeth, sparse postcranial remains (a talus, an incomplete calcaneus and a phalanx II) and a left hemi-mandible. Lacking diagnostic specimens, the specific identity was established thanks to the jaw. Because of its dimensions (see Table S3 in [26]), all the modern South American cervid species or sub-species have been discarded, except B. dichotomus. However, at this time, little or nothing was known about Morenelaphus' dentition. Recently, a university dissertation [55] proposed to attribute the large fossil lower teeth characterized by rounded labial lobids to the taxon Morenelaphus. In fact, Blastoceros' lower teeth show a different morphology concerning this particular feature (compare Figure 8 of this text with Figures 6, 7, 17A and 18A in [55]): their lateral lobids are clearly triangular in shape and not at all rounded. This last kind of morphology could be attributed to Moronelaphus, because at least one mandible with an identical pattern has been collected from a locality (Janaúba, Minas Gerais) which also produced Moronelaphus' antlers [43], although a closer association (a full articulation between the lower jaw and skull with antlers), to our knowledge, has never been found.

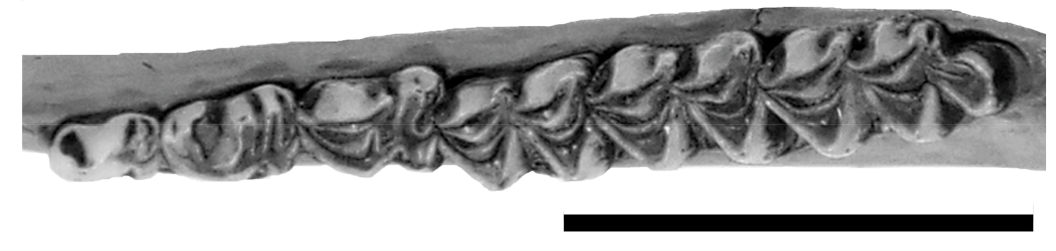

Figure 8. B. dichotomus' left lower teeth (MNRJ 64792). Scale bar $=50 \mathrm{~mm}$.

The mandible (113-123754) from the Toca do Serrote das Moendas (area of the National Park "Serra de Capivara", Piauí, Brazil), identified as B. dichotomus (see Figure 16 in [26]), actually shows more affinity with the jaws attributed to Morenelaphus that to the marsh deer's. The lateral lobids are well rounded (not triangular) and some anterior cingulids that are otherwise unknown on B. dichotomusare also present.

In addition, a large phalanx II (184-20770) was discovered in another fossiliferous locality in the region of the Park [26]: the Toca da Janela da Barra do Antonião (the same site where the talus 184-9871, discussed above was found). The phalanx was compared with some marsh deer's specimens (Figures 9 and 10). B. dichotomus' bone bears a proportionately longer diaphysis (an adaptation for living in marshes) than the fossil one. Clearly the phalanges II, shown in Figure 10, belong to two different species.

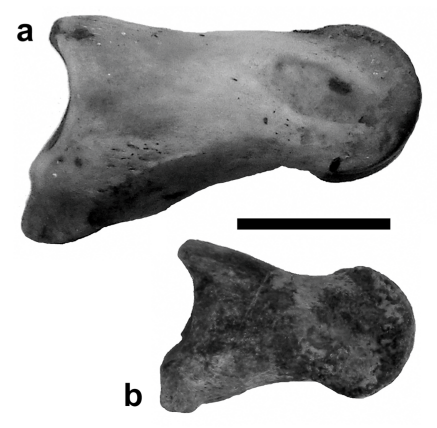

Figure 9. Phalanx II comparison: (a) B. dichotomus (MN 64792); (b) the Toca da Janela da Barra do Antonião (184-20770). Scale bar $=20 \mathrm{~mm}$. 
According to Pêgo [55] and Alcaraz [38], Morenelaphus' skull (except antlers) and upper teeth show some similarities with those of $B$. dichotomus. So, without taking the greatest care, the taxonomic identity of such remains can be easily confused. It is therefore possible that the dental material from the area of NPSC, attributed to the marsh deer, may have belonged to Morenelaphus. It is worth remembering that, before 2014, the differences between the two species were only established by the antlers; at this time, little or nothing was known about the teeth or the postcranial bones.

In an attempt to clarify their differences, the postcranial elements found at Lagoa dos Porcos have been compared to the Blastoceros' bones. The talus of the modern taxon presents some differences from our fossil: it is on average bigger (Lat height $51.08 \mathrm{~mm}$ versus $37.0 \mathrm{~mm}$ ( $\max =53.0 \mathrm{~mm}$; $\min =48.0 \mathrm{~mm})$; Med height $48.42 \mathrm{~mm}$ versus $35.0 \mathrm{~mm}(\max =52.0 \mathrm{~mm} ; \min =45.5 \mathrm{~mm}) ;$ Max DT $33.58 \mathrm{~mm}$ versus $25.5 \mathrm{~mm}(\mathrm{max}=35.5 \mathrm{~mm}$; $\mathrm{min}=31.5 \mathrm{~mm})$; Blastoceros' sample: six specimens from three individuals) and its sides are parallel, without lateral concavity.

The fossil right metacarpal is slightly shorter and less robust at the ends than Blastocerus' one (Tot length $\sim 201 \mathrm{~mm}$ versus $229.25 \mathrm{~mm}$ ( $\max =236.0 \mathrm{~mm}$; $\min =221.5 \mathrm{~mm}$ ); Prox DT $13.0 \mathrm{~mm}$ versus $35.75 \mathrm{~mm}(\max =36.5 \mathrm{~mm} ; \min =35.0 \mathrm{~mm})$; Dist DT $11.5 \mathrm{~mm}$ versus $36.00 \mathrm{~mm}(\max =37.0 \mathrm{~mm}$; $\min =35.5 \mathrm{~mm}$ ); Blastoceros' sample: four specimens from three individuals). At the proximal end, the articular surface of the fossil specimen has a triangular outline (Figure 6a) while that of Blastocerus is clearly trapezoidal.

Finally, the tibia of the modern species is longer than the fossil one (Tot length $=293.0 \mathrm{~mm}$ versus $321.0 \mathrm{~mm}$; only one Blastoceros specimen). If the proximal end of the tibia of both species looks similar, the same cannot be said of the distal end: the antero-lateral eminence of the fossil bone is more pronounced than that of Blastoceros. So, despite the limited sample, the presence of the marsh deer in the NPSC region could be rejected. However, as the spatial relations between the antler fragments and the postcranial bones from the Lagoa dos Porcos are not known, the attribution of these fossils to Morenelaphus remains provisory.

\section{Phalanx II Simpson's diagram}

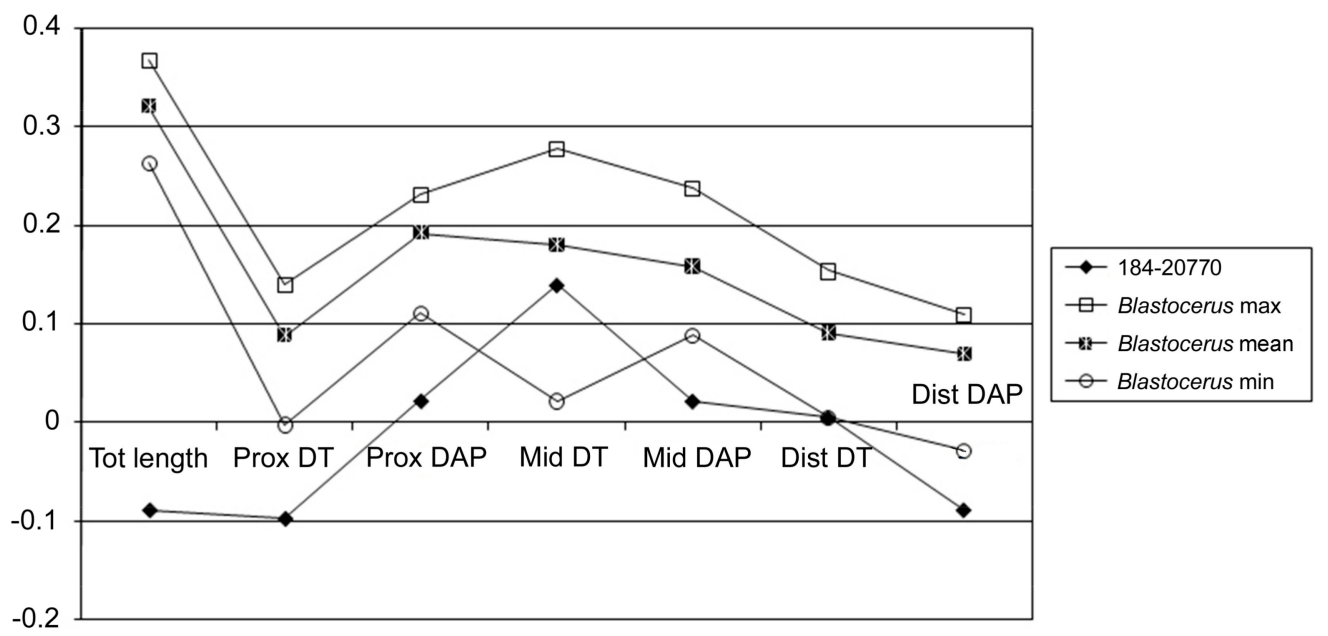

Figure 10. Simpson's diagram of the B. dichotomus' phalanx II (maximum, main and minimum values) and the specimen 184-20770 from the Toca da Janela da Barra do Antonião. The reference is the Mesopotamian fallow deer, Dama mesopotamica (Brooke, 1875).

Regardless of the exact taxonomic affiliation of the mandible (113-123754) and the other postcranial bones, the presence of the genus Morenelaphus in the region of NPSC is established by the fragments of antler collected in the Lagoa dos Porcos. Because of their morphology and size, they can be comfortably 
attributed to Morenelaphus. However, in the absence of more remains (i.e., lack of complete frontal appendages) our taxon can only be defined as Morenelaphus sp.

Pêgo [55] challenged the existence of the two species, M. brachyceros and M. lujanensis. According to the results obtained by his dental analysis, the second taxon would be a junior synonym of the first. That is, doubtless, an interesting proposition, also supported by the fact that the previous chronological distinction between M. brachyceros (Bonaerian) and M. lujanensis (Lujanian) has been shown to be inconsistent by Alcaraz [38]: at least in Argentina, both the species existed from the Bonaerian to the Lujanian. Nonetheless, in our opinion, before confirming the monotypy of the genus Morenelaphus, it would be necessary to extend the analysis to all its known fossil remains.

This genus is beginning to be reported from different Brazilian states, not only from the southern ones or Minas Gerais, where it was traditionally mentioned [35,41,43], but also in the north. Its presence is also reported in Pernambuco [24,45], but without details. Pêgo [55], based on the dentition, states its presence in the fossiliferous deposit of Gruta do Urso (Aurora do Tocantins, Tocantins). In this paper, the discovery of its antlers in the region of NPSC (Piauí) is claimed, farther north than the previous case. However, in MNRJ there exists a fragment of a right jaw (with p2-3 and m1), labelled MN 2819V and identified as "Morenelaphus sp.". It has been collected at the locality of João Cativo, in the coastal municipality of Tapipoca (Ceará). The teeth are a little smaller than those of the mandible 113-123754, but the lateral lobids of the $\mathrm{m} 1$ are clearly rounded, like those of the lower molar from the Piauí (see Figure 18 in [26]) or those figured by Pêgo [55]. We do not know if any antler remains have been found in this locality, but, if its taxonomic identity is confirmed, it would be the northernmost occurrence for this taxon.

Little is known about the Morenelaphus' ecology. This deer is generally considered a browser, occupying open or partially open environments, but always with enough vegetation, just sparse scrublands $[14,44]$. However, its huge geographical range could also be explained by its considerable plasticity [38], probably making it able to adapt to various types of environment.

\subsection{Comparing Karstic Area and Alluvial Plain}

It is worth reporting the preliminary differences found among the cervid remains collected from the fossiliferous localities in the karstic area at the boundaries of NPSC and those found in the Lagoa dos Porcos, lying in the alluvial plain. In the karstic area, 17 fossils have been assembled belonging to a medium-large species. They have been collected from six different sites (Toca dos Pilão, Toca do Barrigudo, Toca do Gordo do Garrincho, Toca do Serrote do Artur, Toca da Janela da Barra do Antonião and Toca do Serrote das Moendas, the last two revealing the larger values of occurrences, respectively, five and six [26]). The sample consists of only three fragments of antlers, very scanty postcranial bones (three, all from the Toca da Janela da Barra do Antonião: the talus and the phalanx II, already discussed above, plus an incomplete calcaneus), all the other fossils being dental vestiges. In contrast, from the same area, the diminutive Mazama (included both M. americana and M. gouazoubira, as recognized by Guérin and Faure [26]) accounted for a larger number of items ( $>100$ specimens), including several cranial and postcranial remains, but with only two antlers, belonging to the same individual (113-124101, from the Toca do Serrote das Moendas).

On the other side, from the Lagoa dos Porcos, only three remains belonging to small cervids have been collected (two dental specimens and a phalanx I, tentatively attributed to the same taxon as the teeth), but 12 belonging to the large genus Morenelaphus have also been collected (if the postcranial remains can be attributed to the same taxon as that of the antlers), nine of which are antler fragments. Thus, the fossil assemblage from the Lagoa dos Porcos seems to differ qualitatively (the larger species is predominant on the smaller ones) and quantitatively (the antler remains are proportionately more numerous than those of other anatomic parts) from the localities lying in the karstic area (Table 4). 
Table 4. Cervids remains found in the Lagoa dos Porcos and in the sites lying in karstic area of the National Park "Serra da Capivara".

\begin{tabular}{ccccc}
\hline $\begin{array}{c}\text { Number and Kind } \\
\text { of Remains }\end{array}$ & $\begin{array}{c}\text { Small } \\
\text { Taxa (Mazama) } \\
\text { Lagoa Dos Porcos }\end{array}$ & $\begin{array}{c}\text { Larger Taxa } \\
\text { (Morenalaphus) } \\
\text { Lagoa Dos Porcos }\end{array}$ & $\begin{array}{c}\text { Small Taxa } \\
\text { (Mazama) } \\
\text { Karstic Area * }\end{array}$ & $\begin{array}{c}\text { Larger Taxa } \\
\text { (Morenalaphus?) } \\
\text { Karstic Area * }\end{array}$ \\
\hline Antlers & 0 & 9 & 2 & 0 \\
Dental $^{1}$ & 2 & 0 & 53 & 14 \\
Postcranial $^{2}$ & $1 ?$ & $3 ?$ & 64 & 3 \\
Tot & $2+1 ?$ & $9+3 ?$ & 119 & 17 \\
\hline
\end{tabular}

* Data for the karstic area from Guérin and Faure [26]; ${ }^{1}$ Including skull, complete or incomplete upper and lower jaws and isolated teeth; ${ }^{2}$ Including complete and partial bones

Despite the fact that this result does not constitute a statistically valid sample and that it is, at present, a hypothesis needing more supporting evidence, there is another datum that helps differentiate the two types of fossiliferous deposits. Guérin and Faure [2], who studied the other fossils from the region, noted the large prevalence of Eremothrium's remains on the other taxa in the alluvial plain sites. Even if there are no known remains of cervids from the other fossiliferous lagoas of the area (Lagoa do Quari, Lagoa São Vitor), the Eremothrium's fossils always outnumber those of all the other taxa. However, in karst sites, even if Eremotherium is always present, it is never as predominant as in the alluvial plain.

The paleoenvironmental reconstruction of the region, for the period during the late Pleistocene-early Holocene, shows a diversified landscape with a mosaic of open, wooded or scrubland areas, much wetter than today [1,2]. So, it is possible that the area near the karstic reliefs and that of the flat alluvial could display quite diverse micro-habits, and that the different cervid taxa were more adapted to one or to the other. In any case, much more data need to be collected, especially from the localities on the alluvial plain, in order to confirm this disparity and provide sound hypotheses to explain it (different paleoenvironments and/or taphonomic bias).

\section{Conclusions}

The analysis of the cervid remains from the Lagoa dos Porcos fossiliferous deposit allowed us to recognize, beside of the genus Mazama, already known as fossil in the area [26], a new Pleistocene deer for the region of NPSC: Morenelaphussp. The ambiguity at the specific level is due to two factors: first, the diagnostic elements, the antlers, found in the lagoa are not complete; second, the taxonomic and stratigraphic variations, within the genus, are not adequately known in the whole South American continent. However, this finding increases the known area of the genus, adding Piauí State. Before, it has been already signaled in the Nordeste, but only in Pernambuco and without any details [24,45]. Today, its presence is evidenced by some fragments of its antlers, which are the most accurate diagnostic elements.

However, despite the new genus, the total number of known species, in the region of the NPSC could not change, as lower teeth previously related to B. dichotomusdo not agree with such determination.

As far as the postcranial bones are concerned, and as the appropriate skeletons are not known, their identification is not easy. In this paper, we describe and represent the most interesting features of the three elements just met in Lagoa dos Porcos (a metacarpal, a tibia, and a talus, all from the right side), in order they can be compared with others found in paleontological localities that produced Morenelaphus' antlers and could constitute reference samples.

The paleoenvironmental reconstructions proposed for the region during the late Pleistocene-early Holocene, do not change. Indeed, they do not depend on a single taxon, but on the whole fauna present in the area during this time. The Quaternary fossil fauna lived in a vegetable landscape more varied than the present one, showing evidence of an environment with water availability throughout the year, 
notably different than the modern caatinga [1,2]. The environment of the region, during the late Pleistocene-early Holocene, would be suitable for this medium-large deer.

Finally, some differences emerge from the comparison of the cervid faunas from, at the one end, the sites in the karstic area of the boundary of NPSC and, at the other, those located in the alluvial plain. In the first case, we found the prevalence of the diminutive species and a relative rarity of antler remains. In the second, deer remains may be absent, or the larger taxon is more abundant. We also observe a higher percentage of frontal appendices than the other types of fossils. This could reflect some micro-environmental disparities between the two areas or simply the involvement of distinct taphonomic patterns (e.g., kind of transport, selective preservation) in the deposit formation. Anyway, ours is just a preliminary analysis: before to state more precise conclusions, is better to complete the taxonomic and taphonomic analyses, in order to collect other data for confirming or modified our hypotheses.

Acknowledgments: I am very grateful to João Alves de Oliveira, Sérgio Maia Vaz ("Departamento de Mastozoologia" of MNRJ), Orlando Grillo ("Departamento de Geologia e Paleontologia" of MNRJ), and R. Randal (Division of the Vertebrate Zoology-Mammals-of AMNH) for allowing me to visit their respective collections and for the support given during them. Eric Delson (City University of New York and AMNH) helped me during my visits in America. I am extremely grateful to Maria Mejandra Alcaraz, who helped me to get a copy of her thesis, essential to this work, to Castor Cartelle who gave me to me some bibliography, and to Rita Garthwaite for the linguistic revision. I also thank Loïc Costeur (Naturhistorisches Museum Basel), Martine Faure (Université Lumières-Lyon II) and Claude Guérin (Université Claude Bernard-Lyon I), recently deceased, for helpful discussions, as well as three anonymous referees and the guest editor of Quaternary journal for their constructive criticism and suggestions, which helped to improve my manuscript. Finally, I am very grateful to the FUMDHAM, in particularly to Anne-Marie Pessis, for the permission to study the fossil remains of the deer from the Lagoa dos Porcos and for all the support given me during the analysis.

Conflicts of Interest: The authors declare no conflict of interest.

\section{References}

1. Guérin, C.; Faure, M. La biodiversité mammalienne au Pléistocène supérieur-Holocène ancien dans la Région du Parc national Serra da Capivara (SE du Piauí, Brésil). In II Sympósio Internacional “O Povoamento das Americas", São Raimundo Nonanto, PI, Brazil; FUMDHAMentos: São Raimundo Nonanto, Brazil, 2008; Volume 7, pp. 80-93.

2. Guérin, C.; Faure, M. Paleontologia da região do Parque Nacional Serra da Capivara. In Os Biomas e as z na Pré-História da Região do Parque Nacional Serra da Capivara, Brasil; Pessis, A.-M., Martini, G., Guidon, N., Eds.; A\&A: São Paulo, Brazil, 2014; ISBN 978-8589313780.

3. Felice, G.D.; Guidon, N.; Mendes, V.R. A evolução da paisagem no Pleistoceno superior/Holoceno, na região do Parque Nacional Serra da Capivara. In Os Biomas e as Seociedades Humanas na Pré-História da Região do Parque Nacional Serra da Capivara, Brasil; Pessis, A.-M., Martini, G., Guidon, N., Eds.; A\&A: São Paolo, Brazil, 2014; ISBN 978-8589313780.

4. Kinoshita, A.; Mayer, E.; Ribau Mendes, V.; Figueiredo, A.M.G.; Baffa, O. Electron spin resonance dating of megafauna from Lagoa dos Porcos, Piauí, Brazil. Radiat. Prot. Dosim. 2014, 159, 212-219. [CrossRef]

5. Guérin, C.; Faure, M. Un nouveau Toxodontidae (Mammalia, Notoungulata) du Pléistocène supérieur du Nordeste du Brésil. Geodiversitas 2013, 35, 155-205. [CrossRef]

6. Faure, M.; Guérin, C.; Parenti, F. Sur l'existence de deux espèces d'Eremotherium E. rusconii (Schaub, 1935) et E. laurillardi (Lund, 1842) dans le Pléistocène supérieur du Brésil intertropical. C. R. Palevol 2014, 13, $259-266$. [CrossRef]

7. Cartelle, C.; De Iuliis, G.; Pujos, F. Eremotherium laurillardi (Lund, 1842) (Xenarthra, Megatheriinae) is the only valid megatheriine sloth species in the Pleistocene of intertropical Brazil: A response to Faure et al., 2014. C. R. Palevol 2014, 14, 15-23. [CrossRef]

8. Scott, K.M.; Janis, C.M. Phylogenetic Relationships of the Cervidae, and the Case for a Superfamily "Cervoidea". In Biology and Management of the Cervidae; Wemmer, C.M., Ed.; Smithsonian: Washington, DC, USA, 1987; ISBN 978-0874749809. 
9. Ginsburg, L.; Azanza, B. Présence de bois chez les femelles du Cervidé miocène Dicrocerus elegans et remarque sur le problème de l'origine du dimorphisme sexuel sur les appendices frontaux des Cervidés. C. $R$ Acad. Sci. Paris 1991, 313, 121-126.

10. Gentry, A.W.; Rössner, G.E.; Heizmann, E.P. Suborder Ruminantia. In The Miocene Land Mammals of Europe; Rössner, G.E., Heissig, K., Eds.; Pfeil: Munich, Germany, 1999; ISBN 978-3931516505.

11. Webb, E.P. Evolutionary history of new world deer. In Antelopes, Deer, and Relatives. Fossil Record, Behavioral Ecology, Systematic, and Conservation; Vrba, E.S., Schaller, G.B., Eds.; Yale University Press: New Haven, CT, USA, 2000; ISBN 978-0300081428.

12. Woodburne, M.O.; Cione, A.L.; Tonni, E.P. Central American provincialism and the Great American Biotic Interchange. In Advances in Late Tertiary Vertebrate Paleontology in Mexico and the Great American Biotic Interchange; Publicación Especial, 4, Carranza-Castañeda, O., Lindsay, E.H., Eds.; Universidad Nacional Autónoma de México, Instituto de Geología and Centro de Geociencias: Ciudad de México, Mexico, 2006; pp. 73-101.

13. Fariña, A.R.; Vizcaíno, S.F.; De Iuliis, G.G. Megafauna: Giant Beasts of Pleistocene South America; Indiana University Press: Bloomington, IN, USA, 2012; ISBN 978-0253002303.

14. Merino, M.L.; Rossi, R.V. Origin, systematics, and morphological radiation of neotropical deer. In Neotropical Cervidology: Biology and Medicine of Latin American Deer; Duarte, B., González, S., Eds.; Funep/IUCN: São Paulo, Brazil, 2010; ISBN 978-8578050467.

15. Mattioli, S. Family Cervidae (Deer). In Handbook of the Mammals of the World-Volume 2-Hoofed Mammals; Wilson, D.E., Mittermeier, R.A., Eds.; Lynx Edicions: Barcelona, Spain, 2011; ISBN 978-8496553774.

16. Carette, E. Cérvidos actuales y fósiles de Sud America. Revisión de las formas extinguidas pampeanas. Ver. Mus. La Plata 1922, 26, 393-472.

17. Heffelfinger, J. Deer of the Southwest; Texas A\&M University Press: College Station, TX, USA; 2006; ISBN 978-1585445158.

18. Weber, M.; Gonzalez, S. Latin American deer diversity and conservation: A review of status and distribution. Écoscience 2003, 10, 443-454. [CrossRef]

19. Groves, C.P.; Grubb, P. Relationships of living deer. In Biology and Management of the Cervidae; Wemmer, C.M., Ed.; Smithsonian: Washington, DC, USA; 1987; ISBN 978-0874749809.

20. Eisenberg, J.F. The contemporary Cervidae of Central and South America. In Antelopes, Deer, and Relatives. Fossil Record, Behavioral Ecology, Systematic, and Conservation; Vrba, E.S., Schaller, G.B., Eds.; Yale University Press: New Haven, CT, USA; London, UK, 2000; ISBN 978-0300081428.

21. Gilbert, C.; Ropiquet, A.; Hassanin, A. Mitochondrial and nuclear phylogenies of Cervidae (Mammalia, Ruminantia): Systematics, morphology, and biogeography. Mol. Phylogen. Evol. 2006, 40, 101-117. [CrossRef] [PubMed]

22. Duarte, J.M.B.; González, S.; Maldonado, J.E. The surprising evolutionary history of South American deer. J. Mol. Phylogen. Evol. 2008, 49, 17-22. [CrossRef] [PubMed]

23. Hassanin, A.; Delsuc, F.; Ropiquet, A.; Hammer, C.; Van Vuuren, B.J.; Matthee, C.; Ruiz-Garcia, M.; Catzeflis, F.; Areskoug, V.; Nguyen, T.T.; et al. Pattern and timing of diversification of Cetartiodactyla (Mammalia, Laurasiatheria), as revealed by a comprehensive analysis of mitochondrial genomes. C. R. Biol. 2012, 335, 32-50. [CrossRef] [PubMed]

24. Cartelle, C. Tempo Passado. Mamíferos do Pleistoceno em Minas Gerais; ACESITA: Belo Horizonte, Brazil, 2008; ISBN 978-8585793012.

25. Cartelle, C. Pleistocene Mammals of the Cerrado and Caatinga of Brasil. In Mammals of the Neotropics (Volume 3): The Central Neotropics: Ecuador, Peru, Bolivia, Brazil; Eisenberg, J.E., Redford, K.H., Eds.; The University of Chicago Press: Chicago, IL, USA, 1999; ISBN 978-0226195421.

26. Guérin, C.; Faure, M. Les Cervidae (Mammalia, Artiodactyla) du Pléistocène supérieur-Holocène ancien de la région du Parc National Serra da Capivara (Piauí, Brésil). Geobios 2009, 42, 169-195. [CrossRef]

27. Labarca, R.E.; Alcaraz, M.A. Presencia de Antifer ultra Ameghino (=Antifer niemeyeri Casamiquela) (Artiodactyla, Cervidae) en el Pleistoceno tardío-Holoceno temprano de Chile central (30-35 S). Andean Geol. 2011, 38, 156-170.

28. Gonzalez, E.; Labarca, R.R.; Chavez-Hoffmeister, M.; Pino, M. First Fossil Record of the Smallest Deer cf. Pudu Molina, 1782 (Artiodactyla, Cervidae), in the Late Pleistocene of South America. J. Vert. Paleontol. 2014, 34, 483-488. [CrossRef] 
29. Magalhães, R.M.M.; Gomide, M.; Bergqvist, L.P. Os cérvidos pleistocênicos da região nordeste brasileira. Acad. Bras. Ciências 1992, 64, 149-154.

30. Oliveira, P.V.; Dutra, T.L.; Zeltzer, F. Megaterídeos (Mammalia, Xenarthra) do Quaternário de Caçapava do Sul, Rio Grande do Sul, com considerações sobre a flora associada. Geol. Colom. 2002, 27, 77-86.

31. Parenti, F. Les industries lithiques du site paléontologique de la Lagoa da Pedra (Pernambuco) et le passage pléistocène-holocène dans le nordeste du Brésil. J. Soc. Am. 1996, 82, 9-29. [CrossRef]

32. Gu\&\#xE9rin, C.; Université Claude Bernard-Lyon I, Lyon, France. Personal communication, 2015.

33. Da Silva, F.M.; da Silva Alves, R.; Barreto, A.M.F.; Bazera de Sá, F.; Borges Lins, A.C.S. A megafauna pleistocênica do Estado de Pernambuco. Est. Geol. 2006, 16, 55-66.

34. Ubilla, M.; Perea, D.; Goso Aguilar, C.; Lorenzo, N. Late Pleistocene vertebrates from northern Uruguay: Tools for biostratigraphic, climatic and environmental reconstruction. Quat. Inter. 2004, 114, 129-142. [CrossRef]

35. Alcaraz, M.A.; Francia, A. Diversidad de cervidae (Mammalia, Artiodactyla) en el Pleistoceno de la Provincia de corrientes, Argentina. Rev. Bras. Paleontol. 2013, 16, 157-166. [CrossRef]

36. Alcaraz, M.A.; Zurita, A.E. Nuevos registros de cérvidos poco conecidos: Epieuryceros cf. proximus Castellanos y Antifer sp. (Mammalia, Artiodactyla, Cervidae). Rev. Mus. Argent. Cienc. Nat. 2004, 6, 41-48.

37. Alcaraz, M.A.; Carlini, A.A. Los cérvidos (Mammalia, Artiodactyla) de las Formaciones Toropí y Yupoí (Pleistoceno medio-tardío) de la provincia de Corrientes, Argentina. Universidad Nacional del Nordeste Comunicaciones Cientificas y Tecnológicas. 2003. Available online: http:/ /200.45.54.140/unnevieja/Web/ cyt/cyt/2003/comunicaciones/06-Biologicas/B-027.pdf (accessed on 27 December 2017).

38. Alcaraz, M.A. Sistemática de los cérvidos (Mammalia, Artiodactyla) del Pleistoceno de las Áreas Extraandinas de Argentina. Pdh, Facultad de Ciencias Naturales y Museo, Universidad Nacional de la Plata, Buenos Aires, Argentina. 2010. Available online: http://sedici.unlp.edu.ar/handle/10915/55174 (accessed on 27 December 2017).

39. Labarca, R.O.; López, P.G. Los mamíferos finipleistocénicos de la Formación Quebrada Quereo (IV Región-Chile): Biogeografía, bioestratigrafía e inferencias paleoambientales. Mastozool. Neotrop. 2006, 13, 89-101.

40. Kerber, L.; Oliveira, E.V. Fósseis de vertebrados da Formação Touro Passo (Pleistoceno Superior), Rio Grande do Sul, Brasil: Atualização dos dados e novas contribuições. Gaea J. Geosc. 2008, 4, 49-64. [CrossRef]

41. Pereira, J.M.; Pereira Lopes, R.; Kerber, L. New remains of Late Pleistocene Mammals from the Chuí Creek, Southern Brazil. Rev. Bras. Paleontol. 2012, 15, 228-239. [CrossRef]

42. Aires, A.S.S.; Lopes, R.P. Representativity of Quaternary mammals from the Southern Brazilian continental Shelf. Rev. Bras. Paleontol. 2012, 15, 57-66. [CrossRef]

43. Cartelle, C. Sobre uma pequena coleção de restos fósseis de mamíferos do Pleistoceno final e Holoceno de Janaúba (MG). In Proceedings of the 11th Congresso Brasileiro de Paleontologia, Curitiba, Paraná, 1-7 September 1989; Sociedade Brasileira de Paleontologia: Curitiba, Brazil, 1989; Volume 11, pp. 635-649.

44. Menégaz, A.N.; Ortiz Jaureguizar, E. Los Artiodáctilos. In Evolución Biológica y Climática de la Región Pampeana Durante los Últimos 5 MILLONEs de Años. Un Ensayo de Correlación con el Mediterráneo Occidental; Alberdi, M.T., Leone, G., Tonni, E.P., Eds.; MNCN: Madrid, Spain, 1995; Volume 12, pp. 311-337.

45. Oliveira, P.V.; Ribeiro, A.M.; Ximenes, X.L.; Viana, M.S.S.; Holanda, E.C. Tayassiudae, Cervidae e Tapiridae da Gruta do Urso Fóssil, Holocene, Parque Nacional de Ubajara, Ceará, Brasil. Rev. Bras. Paleontol. 2014, 17, 417-434. [CrossRef]

46. Benton, M.J. Vertebrate Palaeontology, 3rd ed.; Wiley-Blackwell: Oxford, England, 2004; ISBN 978-0632056378.

47. Gustafson, E.P. An Early Pliocene North American Deer: Bretzia pseudalces, Its Osteology, Biology, and Place in Cervid History. Bull. Mus. Nat. Hist. Univers. Or. 2015, 25, 1-75.

48. Desse, J.; Chaix, L.; Desse-Berset, N. “Osteo” Base-réseau de données ostéométriques pour l'archéozoologie. CNRS Ed. 1986, 20, 1-161.

49. Valli, A.M.F. Le gisement villafranchien moyen de Saint-Vallier (Drôme): Nouvelles données paléontologiques (Cervidae, Bovinae) et taphonomiques. Doc. Lab. Géol. Lyon 2001, 153, 1-275.

50. González, S.; Cosse, M.; Góss Braga, F.; Vila, A.R.; Merino, M.L.; Dellafiore, C.; Cartes, J.L.; Maffei, L.; Gimenez Dixon, M. Pampa Deer Ozotoceros bezoarticus (Linneaus 1758). In Neotropical Cervidology: Biology and Medicine of Latin American Deer; Duarte, B., González, S., Eds.; Funep/IUCN: São Paulo, Brazil, 2010; ISBN 978-8578050467. 
51. Duarte, J.M.B.; Vogliotti, A.; dos Santos Zanetti, E.; Leite de Oliveira, M.; Tiepolo, L.M.; Figueiredo Rodrigues, L.; Bonjorne de Almeida, L. Avaliação do Risco de Extinção do Veado-mateiro Mazama americana Erxleben, 1777, no Brasil. Biodiv. Bras. 2012, 1, 33-41.

52. Alves de Oliveira, J.; Rodrigues Gonçalves, P.; Rodrigues Bonvicino, C. Mamíferos da Caatinga. In Ecologia e Conservação da Caatinga; Leal, I.R., Tabarelli, M., Cordoso da Silva, J.M., Eds.; Universitária da UFPE: Recife, Brazil, 2003; pp. 275-333.

53. Castellanos, A. Notas sobre algunas cornamentas de ciervos de los géneros Epieuryceros, Antifer y Paraceros y descripción de la de Epieuryceros proximus n. sp. Pub. Inst. Fisiogr. Geol. Fac. Cienc. Fís. Quím. Nat. 1945, 24, 5-23.

54. Kraglievich, J.L. Contribución al conocimiento de los cérvidos fósiles del Uruguay. An. Mus. Hist. Nat. Montev. 1932, 2, 355-438.

55. Pêgo, F.B. Revisão taxonômica de Morenelaphus Carette, 1922 (Cetartiodactyla, Cervidae): Uma abordagem morfológica dentária. Master, Universidade Federal do Estado do Rio de Janeiro-UNIRIO, Rio de Janeiro. 2014. Available online: http://www2.unirio.br/unirio/ccbs/ibio/ppgbio/FredericoB.PgoDissertao20122014.pdf (accessed on 27 December 2017).

(c) 2018 by the author. Licensee MDPI, Basel, Switzerland. This article is an open access article distributed under the terms and conditions of the Creative Commons Attribution (CC BY) license (http://creativecommons.org/licenses/by/4.0/). 